Magdalena Rakowska*

\title{
Kompensacja sieroctwa w Domu Dziecka dla Małych Dzieci - na przykladzie Domowego Przedszkola
}

Prezentowany tekst stanowi próbę przybliżenia pola działania absolwentki pedagogiki społecznej ${ }^{1}$ oraz refleksji nad tym działaniem. Bazuje na doświadczeniach, kompetencjach i wiedzy nabytej w toku studiów oraz podczas aktywności zawodowej, realizowanej w placówce opiekuńczo-wychowawczej-w Domowym Przedszkolu przy Domu Dziecka dla Małych Dzieci. Dla podjęcia refleksji nad działaniem pedagoga społecznego w opisywanym obszarze - kompensacji sieroctwa poprzez prowadzenie zajęć opiekuńczo-wychowawczych i dydaktycznych z/dla/wobec małego dziecka, niezbędne jest przybliżenie specyfiki analizowanych działań poprzez przedstawienie kluczowych kategorii, takich jak funkcjonowanie domów dziecka pod względem prawnym i statystycznym oraz cech specyficznych placówki, jaką jest Dom Dziecka dla Małych Dzieci w Łodzi, ze szczególnym uwzględnieniem pracy opiekuńczo-wychowawczej w nim podejmowanej. Na bazie wyjaśnienia powyższych zagadnień oraz analizy literatury poznanej i zinterioryzowanej w toku studiów społeczno-pedagogicznych, przedstawiłam refleksję nad codzienną pracą która obejmuje dylematy, trudności i szanse związane z kompensacją sieroctwa w Domowym Przedszkolu.

Domowe Przedszkole nie jest oddziałem mieszkalnym, lecz przestrzenią nauki i zabawy dla cztero- i pięcioletnich wychowanków. Uczęszcza do niego

\footnotetext{
* Absolwentka studiów magisterskich w Katedrze Pedagogiki Społecznej Uniwersytetu Łódzkiego; Dom Dziecka dla Małych Dzieci w Łodzi.

${ }^{1}$ Ukończyłam studia z pedagogiki społecznej w zakresie pracy opiekuńczej i socjalno-wychowawczej na Wydziale Nauk o Wychowaniu Uniwersytetu Łódzkiego. Podczas kształcenia na I stopniu studiów opracowałam i wdrożyłam projekt socjalny, który był podstawą refleksji nad działaniem, stanowiącej część pracy licencjackiej, złożonej w 2010 r. Studia magisterskie, na tym samym kierunku, zostały zwieńczone badaniami w obszarze kształtowania przestrzeni społecznej w aktywności pracownika socjalnego placówki resocjalizacyjnej. W 2012 r. rozpoczęłam pracę w Domu Dziecka dla Małych Dzieci w Łodzi.
} 
grupa maksymalnie siedmiorga dzieci, którym zajęcia organizuje jeden wychowawca, prowadzący przedszkole. Zajęcia w Domowym Przedszkolu mają na celu przygotowanie wychowanków do rozpoczęcia nauki w przedszkolu miejskim. Są realizowane zgodnie z Podstawą Programową Ministerstwa Edukacji Narodowej dla przedszkoli, oddziałów przedszkolnych w szkołach podstawowych i innych form wychowania przedszkolnego, według autorskiego Programu Pracy Dydaktyczno-Wychowawczej Domowego Przedszkola przy ul. Lnianej, którego cele i zadania oscylują wokół kategorii kompensacji społecznej.

Pojęcie kompensacji społecznej, zgodnie z definicją Heleny Radlińskiej, oznacza, „celowe wyrównywanie braków, uzupełnianie bądź zastępowanie niepomyślnych składników sytuacji osobistej czy grupowej, stwarzanie warunków życia uznawanych za normalne"2. Jest to zatem takie działanie z/dla/wobec Innego, które ma na celu pozytywną zmianę, poprawę sytuacji życiowej. Jednocześnie pedagog społeczny/pracownik socjalny podejmujący się zadania kompensacji dąży do neutralizacji czynników życiowych zagrażających rozwojowi człowieka będącego w sytuacji trudnej, zastępując je elementami środowiska życia, które mogą pozytywnie wpłynąć na jego wszechstronny rozwój. Jako pracownik Domu Dziecka dla Małych Dzieci mogę stwierdzić, że takie rozumienie znaczenia kompensacji społecznej stanowi kwintesencję pracy z małym dzieckiem pozbawionym opieki ze strony rodziny naturalnej, które znalazło się w placówce opiekuńczo-wychowawczej.

\section{Funkcjonowanie domów dziecka w Polsce - kluczowe pojęcia, założenia prawne i dane statystyczne}

Zgodnie z założeniem, że ,istota ludzka może być rozumiana i wspomagana jedynie w kontekście bliskich i znaczących systemów ludzkich, których jest częścią i spośród których najważniejsza jest rodzina"”, w pracy socjalnej/społecznej nadrzędne znaczenie ma wspieranie rodziny w prawidłowym wypełnianiu funkcji rodzicielskich. Takie pojmowanie rodziny przyczyniło się do reorientacji poglądów na pieczę zastępcza, czego skutkiem jest intensyfikacja działań na rzecz rodziny, ze szczególnym uwzględnieniem pracy z rodzinami zagrożonymi umieszczeniem dziecka w systemie opieki instytucjonalnej ${ }^{4}$. Zgodnie z ustawą o wspieraniu rodziny i pieczy zastępczej z dnia 9 czerwca 2011 r., która stanowi naczelny akt prawny regulujący zinstytucjonalizowaną pomoc rodzinie, „w przypadku niemożności zapewnienia dziecku opieki i wychowania przez rodziców realizowana jest piecza

${ }^{2}$ H. Radlińska, Pedagogika społeczna, Ossolineum, Warszawa 1961, s. 370-371.

${ }^{3}$ J. Bragiel, Rodzina obszarem pracy socjalnej, [w:] J. Brągiel, P. Sikora (red.), Praca socjalna - wielość perspektyw. Rodzina - multikulturowość - edukacja, Wydawnictwo Uniwersytetu Opolskiego, Opole 2004, s. 12.

${ }^{4}$ Por. M. Kaczmarek, Dekada przekształceń domów dziecka, „Problemy Opiekuńczo-Wychowawcze" 2010, nr 1. 
zastępcza"s. Jest ona organizowana przez władze powiatu i może być realizowana $\mathrm{w}$ formie rodzinnej i instytucjonalnej ${ }^{6}$. Zadaniem rodzinnej pieczy zastępczej jest stworzenie ,jednej, wielodzietnej rodziny dla dzieci, którym nie znaleziono rodziny zastępczej lub przysposabiającej"', a stanowiąc warunki wychowania w rodzinie dla dzieci w różnym wieku, dawanie możliwości zaspokajania potrzeby miłości i przynależności. Jak wynika z rozporządzenia Ministra Pracy i Polityki Społecznej z dnia 19 października 2007 r. w sprawie placówek opiekuńczo-wychowawczych, opiekunowie w rodzinnym domu dziecka podejmują role rodziców, zatem istnieje szansa na wytworzenie się między dziećmi i zastępczymi rodzicami emocjonalnej więzi zbliżonej do tych rodzinnych.

Wśród form rodzinnej pieczy zastępczej ustawodawca wymienia:

1) rodziny zastępcze:

a) spokrewnione;

b) niezawodowe;

c) zawodowe, w tym zawodowa pełniąca funkcję pogotowia rodzinnego i zawodowa specjalistyczna;

2) rodzinne domy dziecka ${ }^{8}$.

Jednak, jak wynika $\mathrm{z}$ obserwacji sytuacji dzieci pozbawionych opieki ze strony rodziców naturalnych, w Łodzi małoletni nadal długo oczekują na umieszczenie w pieczy rodzinnej, gdzie liczba miejsc jest ograniczona, mimo że dane statystyczne zawarte w tab. 1 ukazują dość pomyślny obraz zjawiska.

Tabela 1. Dzieci w instytucjonalnej i rodzinnej pieczy zastępczej - stosunek liczbowy i procentowy. Stan z dnia 31.12.2013 r.

\begin{tabular}{|c|c|c|c|c|c|}
\hline \multirow[b]{2}{*}{ Polska } & \multicolumn{2}{|c|}{ Piecza rodzinna } & \multicolumn{2}{|c|}{ Piecza instytucjonalna } & \multirow{2}{*}{$\begin{array}{c}\text { Udział procentowy } \\
\text { liczby dzieci } \\
\text { umieszczonych } \\
\text { w pieczy } \\
\text { instytucjonalnej } \\
\text { w pieczy ogółem } \\
25,2 \%\end{array}$} \\
\hline & $\begin{array}{c}39,2 \text { tys. } \\
\text { rodzin }\end{array}$ & $\begin{array}{l}\text { 57,3 tys. } \\
\text { dzieci }\end{array}$ & $\begin{array}{c}951 \\
\text { placówek }\end{array}$ & $\begin{array}{c}\text { 19,3 tys. } \\
\text { dzieci }\end{array}$ & \\
\hline $\begin{array}{l}\text { Województwo } \\
\text { łódzkie }\end{array}$ & 3129 rodzin & 4407 dzieci & 58 placówek & 1350 dzieci & $23,4 \%$ \\
\hline
\end{tabular}

Źródło: Główny Urząd Statystyczny, Opieka nad dzieckiem pozbawionym opieki, Warszawa 2014, s. 1-3.

${ }^{5}$ Ustawa o wspieraniu rodziny i pieczy zastępczej z dnia 9 czerwca 2011 r., art. 32, s. 19 , http://isap.sejm.gov.pl/DetailsServlet?id=WDU20111490887 (dostęp: 2.03.2016).

${ }^{6}$ Tamże, art. 34.

${ }^{7}$ Rozporządzenie Ministra Pracy i Polityki Społecznej z dnia 19 października 2007 r. w sprawie placówek opiekuńczo-wychowawczych.

${ }^{8}$ Tamże, art. 39, s. 24. 
Jak wynika $\mathrm{z}$ analizy danych statystycznych zawartych $\mathrm{w}$ tab. 1, odsetek dzieci umieszczonych $w$ instytucjonalnej pieczy zastępczej stanowi około $25 \%$ ogółu dzieci wychowujących się poza rodziną naturalną. W Łodzi liczba ta jest nawet nieznacznie niższa. Zatem niemal co czwarte dziecko pozbawione opieki i wsparcia ze strony rodziców naturalnych przebywa w środowisku instytucjonalnym, czyli w jednej z takich placówek, jak:

1) regionalne placówki opiekuńczo-terapeutyczne;

2) interwencyjne ośrodki preadopcyjne;

3) placówki opiekuńczo-wychowawcze:
a) typu socjalizacyjnego;
b) typu interwencyjnego;
c) typu specjalistyczno-terapeutycznego;
d) łączące zadania9.

„W regionalnej placówce opiekuńczo-terapeutycznej są umieszczane dzieci wymagające szczególnej opieki, które ze względu na stan zdrowia wymagający stosowania specjalistycznej opieki i rehabilitacji nie mogą zostać umieszczone w rodzinnej pieczy zastępczej lub w placówce opiekuńczo-wychowawczej"10. Placówki tego typu funkcjonują jak na razie tylko w kilku regionach w Polsce. W województwie łódzkim nie ma regionalnej placówki opiekuńczo-terapeutycznej ${ }^{11}$. Na terenie regionu łódzkiego funkcjonuje od października 2016 r. ośrodek preadopcyjny - jest to Interwencyjny Ośrodek Preadopcyjny Tuli-Luli przy Fundacji Gajusz w Łodzi, czyli placówka dla dzieci do 1. roku życia, które przygotowywane są do przysposobienia i ze względu na konieczność specjalistycznej opieki nie mogą być umieszczone w placówce innego typu ${ }^{12}$.

Placówka opiekuńczo-wychowawcza typu specjalistyczno-terapeutycznego sprawuje opiekę nad dziećmi niepełnosprawnymi, wymagającymi stosowania specjalistycznej terapii w celu wyrównywania opóźnień rozwojowych i zaległości edukacyjnych. Wychowawcy i terapeuci prowadzą zatem, ,zajęcia wychowawcze, socjoterapeutyczne, korekcyjne, kompensacyjne, logopedyczne, terapeutyczne, rekompensujące braki w wychowaniu w rodzinie i przygotowujące do życia społecznego, a dzieciom niepełnosprawnym [zapewniaja] także odpowiednią rehabilitację i zajęcia rewalidacyjne"13.

Placówka interwencyjna podejmuje działania ratownicze w sytuacji kryzysowej dla dziecka i ,przyjmuje [...] w sytuacjach wymagających natychmiastowego

\footnotetext{
${ }^{9}$ Ustawa o wspieraniu rodziny i pieczy zastępczej..., art. 93, s. 54 (dostęp: 4.03.2016).

${ }^{10}$ Tamże, art. 109, s. 66.

${ }^{11}$ M. Łongwa-Kurosz, Rejestr wolnych miejsc w placówkach opiekuńczo-wychowawczych, regionalnych placówkach opiekuńczo-terapeutycznych i interwencyjnych ośrodkach preadopcyjnych funkcjonujacych na terenie województwa tódzkiego, stan z dnia 31.01.2016 r.

${ }^{12}$ Ustawa o wspieraniu rodziny i pieczy zastępczej..., art. 111, s. 67 (dostęp: 8.03.2016).

${ }^{13}$ Tamże, art. 105, s. 63-64.
} 
rozpoczęcia sprawowania opieki i wychowania"14. Pobyt w placówce interwencyjnej ma formę doraźną i nie może trwać dłużej niż trzy miesiące.

Placówka typu socjalizacyjnego zapewnia wychowankom stałą, całodobową opiekę, zajęcia wychowawcze i terapeutyczne, zaspokaja ich podstawowe potrzeby, a także podejmuje pracę $\mathrm{z}$ rodziną naturalną dziecka $\mathrm{w}$ celu powrotu do rodziny naturalnej lub przysposobienia ${ }^{15}$. Placówką opiekuńczo-wychowawczą typu socjalizacyjnego jest dom dziecka. W Łodzi funkcjonuje 16 domów dziecka, w których umieszczani są wychowankowie od 4. do 21. roku życia (łącznie 329 miejsc dla 326 wychowanków ${ }^{16}$ ) - część z nich to placówki zajmujące się procesem usamodzielniania pełnoletnich wychowanków oraz Dom Dziecka dla Małych Dzieci, w którym znajdują się wychowankowie w wieku od 0. do 21. roku życia (łącznie 90 miejsc dla wychowanków - dzieci, a także małoletnich matek, do czasu ich usamodzielnienia $\left.{ }^{17}\right)$.

\section{Dom Dziecka dla Małych Dzieci w Lodzi - cechy specyficzne i funkcjonowanie}

Dom Dziecka Dla Małych Dzieci w Łodzi składa się z trzech domów - głównego przy ul. Drużynowej (funkcjonującego nieprzerwanie od 1946 r.) ${ }^{18}$ oraz dwóch filii: przy ul. Lnianej (założonej pod koniec lat 70. ubiegłego stulecia) i ul. Zbocze (od 2007 r.). Jest specyficznym rodzajem placówki opiekuńczo-wychowawczej, choćby z dwóch względów - przyjmuje dzieci już od pierwszych dni życia (dom przy ul. Drużynowej specjalizuje się w opiece nad dziećmi do ukończenia 12 miesięcy), przebywają w nim także nieletnie matki wraz ze swoimi dziećmi (dom przy Drużynowej oraz filia przy ul. Zbocze), ponadto łączy w sobie funkcję socjalizacyjną i interwencyjną (przyjmowane są tam dzieci wymagające niezwłocznego podjęcia opieki na mocy postanowień sądu o umieszczeniu w placówce w trybie natychmiastowym). Natomiast dom przy ul. Lnianej charakteryzuje się tym, że jest w nim prowadzone Domowe Przedszkole, które stanowi odrębny oddział - wewnętrzne przedszkole zajmujące się przygotowaniem wychowanków filii do rozpoczęcia nauki w przedszkolach miejskich.

W trzech opisywanych domach jest łącznie 90 miejsc, natomiast przebywa $\mathrm{w}$ nich niekiedy nawet o ponad $1 / 3$ dzieci więcej. Wynika to $\mathrm{z}$ faktu, że pozostałe łódzkie domy dziecka nie sprawują opieki nad niemowlętami oraz dziećmi w wieku poniemowlęcym, rzadko przedszkolnym, a placówka, pełniąc funkcje

\footnotetext{
${ }^{14}$ Rozporządzenie Ministra Pracy i Polityki Społecznej z dnia 19 października 2007 r....

${ }^{15}$ Tamże.

${ }^{16}$ M. Łongwa-Kurosz, Rejestr wolnych miejsc w placówkach opiekuńczo-wychowawczych..., s. $10-14$.

${ }^{17}$ Tamże.

${ }^{18}$ www.domdlamalucha.info (dostęp: 14.03.2016).
} 
interwencyjne, podejmuje, obok działań kompensacyjnych, w dużej mierze także zadania ratownicze (dotyczy to szczególnie dzieci najmłodszych, które pozostawione bez opieki ze strony dorosłych znajdują się w sytuacji zagrożenia życia).

\section{Praca opiekuńczo-wychowawcza w Domu Dziecka dla Małych Dzieci}

W placówce zatrudnieni są, podobnie jak w innych domach dziecka, wychowawcy, pedagodzy, pracownicy socjalni oraz pracownicy administracyjni, ale także, co wyróżnia Dom dla Malucha, pracują w nim opiekunki dziecięce, terapeuta, logopeda, salowe i pielegniarki (co specyficzne, są to jedynie kobiety - mężczyźni niezwykle sporadycznie aplikują o pracę w Domu Dziecka dla Małych Dzieci).

Do głównych zadań pracowników placówki, obok scharakteryzowanej we wstępie kompensacji społecznej, należą opieka, pomoc w rozwoju, niekiedy także ratownictwo. Jak zauważa Wanda Terlecka, „opieka i wychowanie zakładowe są [...] realizowane przez osoby posiadające przygotowanie zawodowe, których codzienna praca jest zorganizowana podobnie, jak w innych zawodach" ${ }^{19}$. Z jednej strony $\mathrm{w}$ domu dziecka, podobnie jak w innych publicznych placówkach czy prywatnych przedsiębiorstwach, istnieje podział na przełożonych i podwładnych, funkcjonują sformalizowane zakresy zadań na poszczególnych stanowiskach, obowiązujące procedury postępowania, których należy przestrzegać. Z drugiej jednak - jest to dom, w którym przez kilka tygodni, czy raczej miesięcy, a nawet lat, mieszkają dzieci, spędzając w nim całą dobę.

Do pracy w sektorze pomocy społecznej, do którego należą domy dziecka, przyjmowani są wykształceni specjaliści, którzy powinni się legitymować zarówno wykształceniem wyższym, jak i pewnymi kompetencjami oraz cechami osobowości. Wanda Terlecka ${ }^{20}$ podkreśla, że w pracy wychowawczej istotne jest nie tylko wykształcenie pedagogiczne - poza wiedza, liczy się także charakter pracownika. Wychowawca, który nie odnajdzie w sobie pokładów cierpliwości czy opanowania, może mieć duże trudności w pracy z dzieckiem osieroconym ${ }^{21}$. Duże znaczenie w nabywaniu cierpliwości i zdolności nawiązywania relacji człowiekiem, który znalazł się w sytuacji trudnej, mają praktyki zawodowe. Rzetelne odbywanie praktyk, a w szczególności realizacja projektu socjalnego (jako elementu kształcenia w toku studiów I stopnia) uczy cierpliwości, pokory i daje szansę na weryfikację swoich umiejętności praktycznego działania.

${ }^{19}$ W. Terlecka, Dom dziecka, [w:] K. Ablewicz, T. Pilch (red.), Encyklopedia pedagogiczna XXI wieku, Wydawnictwo Akademickie „Żak”, Warszawa 2008, s. 741.

${ }^{20}$ Tamże, s. 742.

${ }^{21}$ Tamże. 
Dom przy ul. Lnianej składa się z trzech oddziałów-mieszkań oraz Domowego Przedszkola. W poszczególnych mieszkaniach znajdują się grupy 10-12 dzieci w wieku od roku do 9 lat ${ }^{22}$ wraz ze swoim rodzeństwem. To, do którego z mieszkań trafi dziecko (lub rodzeństwo), zależy od liczby wolnych miejsc w mieszkaniu (stąd też różnice wiekowe u wychowanków, którzy nie są dobierani ze względu na wiek).

Codzienna rzeczywistość w placówce toczy się według rytmu dobowego - dzień/noc (tak też ustalane są 12-godzinne dyżury pracowników poszczególnych mieszkań). Rytm dnia określają poszczególne posiłki, czas snu i czas zabawy. Zastępowanie niepomyślnej sytuacji życiowej dzieci takimi elementami życia, które mają za zadanie odbudować poczucie bezpieczeństwa i zaspokoić podstawowe potrzeby biopsychiczne, polega w dużej mierze na realizowaniu codziennego rytmu dnia. Posiłki są codziennie o tej samej porze, podobnie jak kąpiel czy pora snu. Dzieci po śniadaniu i po podwieczorku mają czas na zabawę, zajęcia terapeutyczne, starsi wychowankowie wychodzą do przedszkola i szkoły, odbywają się także odwiedziny rodziców.

Praca na oddziale w znacznym stopniu obejmuje czynności opiekuńcze. Opieka ,jest to działanie zorganizowane, zaplanowane, poprzedzone diagnozą potrzeb wychowanka, które polega na dostarczeniu środków, niezbędnych do zaspokojenia braków”23. Opiekun przejmuje pełną odpowiedzialność za losy podopiecznego. W pozytywnym rozumieniu, opieka prowadzi do wyposażenia wychowanka w kompetencje, niezbędne do usamodzielnienia, jednak negatywnie pojmowana i nadużywana może prowadzić do ubezwłasnowolnienia ${ }^{24}$.

W przypadku pracy z małym dzieckiem niezbędne jest wykonywanie czynności opiekuńczych, gdyż ich zaniechanie mogłoby narazić na szwank zdrowie i bezpieczeństwo zupełnie niesamodzielnego dziecka, a w konsekwencji doprowadzić do sytuacji, w której niezbędne stałyby się czynności ratownicze. Zadania z zakresu opieki nad dziećmi, czyli wykonywanie czynności pielęgnacyjnych i higienicznych stanowią istotny punkt orientujący pracę wychowawców na oddziale (ze względu na przeważającą liczbę zatrudnionych wychowawców nad opiekunkami czy salowymi, podział zadań wskazuje na silne zazębianie się obowiązków).

Wychowankowie Domu dla Malucha to w dużej mierze dzieci z zaburzeniami zdrowotnymi - obok deficytów, takich jak FAS, dziecięce porażenie mózgowe, zespół Downa czy upośledzenie umysłowe, wielokrotnie można odnotować obniżoną odporność organizmu i podatność na wiele chorób wirusowych czy bakteryjnych (grypa jelitowa, stany zapalne dróg oddechowych

\footnotetext{
${ }^{22}$ Stan z dnia 20.03.2016 r.

${ }^{23}$ H. Radlińska, Pedagogika społeczna, s. 340.

${ }^{24}$ Tamże, s. 341.
} 
występują z dużym nasileniem, często dotykając kilkoro dzieci w tym samym czasie). Podczas dyżuru dziennego w placówce jest obecna pielęgniarka, która podejmuje czynności medyczne. W czasie nocnego dyżuru, kiedy objawia się wiele niepokojących sygnałów zdrowotnych bywa, pielęgniarka nie dyżuruje (ze względów kadrowych). Wówczas wychowawca jest zdany na siebie i ewentualną pomoc koleżanek $\mathrm{z}$ innych mieszkań. Niejednokrotnie odnotowałam zarówno w swojej praktyce, jak i koleżanek przekazujących opiekę nad grupą wychowanków, sytuacje zagrożenia zdrowia i życia dziecka, kiedy konieczne było udzielenie pierwszej pomocy. Niektóre dzieci mają tendencję do zadławień, wysoko gorączkują, co jest szczególnie niebezpieczne u epileptyków (zwłaszcza, gdy choroba wcześniej się nie ujawniła), zdarzają się także przypadki duszności i utraty przytomności. Wychowawca, którego głównym obowiązkiem jest opieka nad dziećmi i zapewnienie im poczucia bezpieczeństwa (co jest także głównym zakresem odpowiedzialności ${ }^{25}$ ), musi zatem wykazywać się umiejętnością szybkiej diagnozy (także przedmedycznej), racjonalnej oceny sytuacji i właściwego reagowania. $\mathrm{W}$ opisywanych przypadkach powinien także dysponować wiedzą z zakresu pediatrii i znajomością swoich wychowanków (co jest szczególnie trudne, jeśli dziecko właśnie zostało przywiezione do placówki z interwencji policji w środowisku rodzinnym). Szkolenie BHP, na którym omawiane są tematy z zakresu udzielania pierwszej pomocy, prowadzone dla pracowników rozpoczynających aktywność zawodową jest systematycznie ponawiane. $\mathrm{Na}$ podstawie własnych doświadczeń mogę jednak stwierdzić, że wiedza medyczna, jaka okazuje się niezbędna w pracy z małym dzieckiem w chwili podejmowania pracy, jest niewielka i niekiedy niewystarczająca. Dzięki wsparciu, jakie otrzymałam od wieloletnich pracowników, nabywanemu doświadczeniu oraz samokształceniu udało mi się uzupełnić niezbędną wiedzę medyczną. Niestety, podczas studiów pedagogicznych zdecydowanie brakuje zajęć z zakresu udzielania pomocy w razie zagrożenia zdrowia i życia, biologii czy medycyny, a przecież pedagog społeczny, podejmując pracę zawodową, zawsze działa z/dla/wobec drugiego człowieka (na różnych etapach jego życia i rozwoju). Interesuje się on drugim człowiekiem, ujmowanym całościowo, a więc również $\mathrm{w}$ aspekcie biologicznym. Dlatego uważam, że studia pedagogiczne powinny dawać studentowi możliwość uzyskania kompetencji, takich jak udzielanie pierwszej pomocy, a także zapewnić zdobycie podstawowej wiedzy medycznej, obejmującej diagnozowanie chorób specyficznych dla poszczególnych etapów rozwoju człowieka oraz deficytów rozwojowych. Dzięki takiej wiedzy i umiejętnościom absolwent pedagogiki społecznej mógłby udzielać fachowych porad w toku pracy socjalnej/ wychowawczej (choćby, do jakiego lekarza się udać, aby w pełni zdiagnozować

${ }^{25}$ Zakres obowiązków odpowiedzialności i uprawnień na stanowisku wychowawcy Domu Dziecka dla Małych Dzieci w Łodzi, cz. III, pkt 1, s. 2. 
dolegliwości dziecka) oraz szybko reagować w sytuacjach zagrożenia zdrowia i życia swoich podopiecznych, pomijając etap bezradności, paniki i żmudnego nabywania kompetencji w czasie pracy.

\section{Praca wychowawcza w Domowym Przedszkolu}

Zajęcia w Domowym Przedszkolu odbywają się od poniedziałku do piątku, w godzinach od 9 do 15 (z przerwą na obiad). Uczestniczy w nich sześcioro lub siedmioro dzieci (liczba ta zależy od tego, ilu cztero- i pięciolatków jest w placówce). Zgodnie z wytycznymi MEN oraz metodyką pracy z dzieckiem w wieku przedszkolnym zajęcia dydaktyczne obejmują około 1/5 czasu spędzanego w przedszkolu, $1 / 5$ to zorganizowane zabawy ruchowe, tyle samo powinna trwać dowolna zabawa dzieci, a pozostały czas zajmują czynności opiekuńcze i samoobsługowe (jak choćby posiłki czy przebranie się do wyjścia na spacer), organizacyjne oraz inne zabawy.

Zajęcia przedszkolne mają na celu wspieranie wszechstronnego rozwoju dzieci, ze szczególnym uwzględnieniem sfer społecznej, intelektualnej, zdolności samoobsługowych, wdrażanie do nauki czytania i pisania oraz poszerzanie wiedzy o otaczającym świecie ${ }^{26}$. Poszczególne zajęcia obejmują bloki tematyczne, rozwijające zdolności komunikacyjne i zasób słownictwa, sprawność manualną, koordynację wzrokowo-ruchową, kształtują spostrzegawczość i motorykę dużąa ${ }^{27}$.

Wychowankowie domów dziecka, w wyniku zaniedbań rodziców, a także przebywania $\mathrm{w}$ placówce opiekuńczo-wychowawczej mogą posiadać rozmaite wady rozwojowe ${ }^{28}$, ponadto są narażeni na zaburzenia zachowania, trudności w nauce i prawidłowym funkcjonowaniu ${ }^{29}$. Dzieci wychowujące się w Domu Dziecka dla Małych Dzieci mają znaczące opóźnienia rozwojowe, co wyraźnie podkreśla psycholog w swoich opiniach i pracownicy Poradni Psychologiczno-Pedagogicznych, badający wychowanków placówki. Wynikają one w dużej mierze z zaniedbań rodziców biologicznych zarówno w sferze wzrostu (począwszy od okresu ciąży, kiedy matki wychowanków często nadużywają alkoholu,

${ }^{26}$ Podstawa Programowa Ministerstwa Edukacji Narodowej dla przedszkoli, oddziałów przedszkolnych w szkołach podstawowych i innych form wychowania przedszkolnego.

${ }^{27}$ Jako wychowawca w przedszkolu realizuję Program Pracy Dydaktyczno-Wychowawczej Domowego Przedszkola na rok szkolny 2015/2016 opracowany na podstawie wytycznych Ministerstwa Edukacji Narodowej oraz autorskich Planów Pracy Dydaktyczno-Wychowawczej na I i II semestr bieżącego roku szkolnego, zawierających miesięczne i tygodniowe rozkłady zajęć dla dzieci przedszkolnych.

${ }^{28}$ Por. S. Siwek, Sieroctwo społeczne w genezie nieprawidłowego rozwoju, „Problemy Opiekuńczo-Wychowawcze" 2009, nr 6.

${ }^{29}$ Por. M. Andrzejewski, Domy na piasku. Rzecz o sieroctwie i domach dziecka, Wydawnictwo „W drodze”, Poznań 1997. 
niewłaściwie się odżywiają, nie troszczą się o zdrowie dziecka i swoje przez zaniedbania higieniczne, medyczne i żywieniowe), jak i w sferze socjokulturowej, a także deficytów psychofizycznych (wielu wychowanków wymaga korekcji wzroku, ma stwierdzony niedosłuch i inne niesprawności, w wyniku trudnych doświadczeń wymaga pracy nad rozpoznawaniem i okazywaniem emocji). Z tych względów podopieczni mają trudności z nauką, obniżoną sprawność poznawczą i mniejszą wiedzę o świecie, kłopoty z odnalezieniem się w grupie rówieśniczej. Może to skutkować utrudnionym rozpoczęciem edukacji, co z kolei generuje trudności i niepowodzenia szkolne na dalszym etapie edukacji. Wszelkie działania podejmowane w celu zapobiegania negatywnym zdarzeniom wymienionym powyżej obejmują zadania z zakresu profilaktyki i kompensacji społecznej.

Mali wychowankowie Domu Dziecka dla Małych Dzieci spędzają wiele czasu w swoich mieszkaniach. Jedynie przy sprzyjających warunkach pogodowych i zdrowotnych wychodzą na spacery czy do ogrodu. W przeciwieństwie do dzieci wychowujących się w domu rodzinnym nie odwiedzają krewnych, gdyż to rodzice przychodzą do wychowanków placówki (ze zróżnicowaną częstotliwością, zależną od potrzeb i możliwości dorosłych), nie uczestniczą w codziennych sytuacjach domowych (takich jak zakupy, gotowanie czy sprzątanie) - wszelkie ich potrzeby zaspokajane są na oddziale, niejako dostarczane w postaci gotowych produktów lub sztucznie organizowanych sytuacji wychowawczych. Atrakcją, a także swoistą nobilitacją dla wychowanka jest rozpoczęcie nauki w Domowym Przedszkolu. Wówczas dziecko wychodzi z grona maluchów i wkracza w świat „dużych dzieci”, które chodzą do przedszkola. Nie jest to co prawda przedszkole zewnętrzne, które stanowi najwyższy niemal zaszczyt i uznanie „dorosłości” (obok rozpoczęcia nauki w szkole) i umożliwia codzienne wyjścia poza placówkę, spotkania z rówieśnikami wychowującymi się w rodzinach naturalnych oraz inne atrakcje (wycieczki, świętowanie uroczystości poza placówką czy choćby spędzanie czasu w sposób inny od młodszych wychowanków), lecz i tak stanowi nie lada atrakcję, mimo że znajduje się w tym samym budynku, co oddziały mieszkalne. Jak zauważa Jolanta Dunaj ${ }^{30}$, placówka opiekuńczo-wychowawcza przejawia cechy instytucji totalnej, takie jak: głęboka ingerencja w osobowość uczestników i definiowanie jej bez udziału (czasem też zgody) samych uczestników, ograniczona autonomia dziecka w sprawach codziennych, wyższość interesu instytucji nad potrzebami dziecka, postawienie w opozycji wychowawcy (jako zwierzchnika) i wychowanka (jako podwładnego). Autorka zauważa, że te cechy są charakterystyczne zarówno dla ogromnej placówki, jak i tej małej ${ }^{31}$, gdyż system instytucjonalnych norm i reguł zawsze odróżnia ją od rodziny. Na podstawie

${ }^{30}$ J. Dunaj, Komunikacja stowna w placówce opiekuńczo-wychowawczej, ,Problemy Opiekuńczo-Wychowawcze" 2009, nr 7.

${ }^{31}$ Tamże. 
doświadczeń zawodowych i praktyk studenckich w jednym z domów dziecka na terenie Łodzi w pewnym zakresie muszę zgodzić się $\mathrm{z}$ tym stwierdzeniem. $\mathrm{Z}$ pewnością ograniczona jest swoboda dziecka w istotnych sprawach - wychowankowie placówki nie mogą, ze względów organizacyjnych, finansowych czy kadrowych, decydować o tym, kto z personelu w danym dniu jest na dyżurze (dzieci często mają swoje preferencje, jednak ulubiona ciocia akurat ma wolne i przychodzi dopiero za kilka dni), jak wyglądają posiłki czy rozkład dnia. Jednak opisywaną przez J. Dunaj opozycję wychowankowie-wychowawca w pracy z małym dzieckiem można niwelować za pomocą dążenia do równoważenia relacji i pomocy w rozwoju poprzez towarzyszenie społeczne, zmierzając do działań wspierających rozwój wychowanków.

Pedagogika społeczna postrzega rozwój człowieka jako „ukierunkowany proces zmian, zmierzających przez określone fazy do osiagnięcia wyższych form strukturalnych i funkcjonalnych”32. Zatem jest „komplikowaniem się i wzbogacaniem stosunków jednostki ze światem" ${ }^{\prime 33}$. W takim rozumieniu praca wychowawcza bazuje na zadaniach związanych z pomocą w rozwoju, rozumianą jako „wprowadzanie w wartości, dopomaganie we wzroście i wrastaniu w środowisko społeczne, wspomaganie, ochranianie rozwoju przed zaburzeniami [...], «służbą rozwojowi», [która nie może] «łamać i gasić», lecz powinna «dopomagać do prostowania i rozświetlania od wewnątrz»” ${ }^{34}$. Według H. Radlińskiej „za nikogo nie można się rozwijać, można jednak ochraniać rozwój przed zaburzeniami i wspomagać go, dostarczając pożywek i podniet" ${ }^{35}$.

Zgodnie z myśleniem społeczno-pedagogicznym, zadaniem wychowawcy jest otwieranie przed wychowankiem drzwi do samodzielności i stwarzanie pomyślnych warunków do rozwoju, usuwanie barier i niekorzystnych sytuacji oraz wspieranie w dążeniu do celu, jakim jest wszechstronny rozwój. Odbywa się on na drodze wzrostu biologicznego, wrastania społecznego i wprowadzania w wartości kultury ${ }^{36}$. Wspieranie wzrostu w pracy opiekuńczo-wychowawczej w Domu Dziecka dla Małych Dzieci wyraża się w dbałości o zaspokojenie potrzeb bytowych dzieci, czynnościach pielęgnacyjnych, trosce o ich zdrowie, zbilansowaną dietę, obserwację stanu zdrowia, terapię pedagogiczną i rehabilitację ruchową. $\mathrm{W}$ przedszkolu natomiast bazuję na prowadzeniu zajęć rozwijających motorykę małą i dużą, stymulacji psychoruchowej oraz nauczaniu polisensorycznym.

${ }^{32}$ E. Marynowicz-Hetka, Pedagogika społeczna. Podręcznik akademicki, t. 1, PWN, Warszawa 2007, s. 133.

${ }^{33}$ M. Tyszkowa, Kultura symboliczna. Wartości i rozwój jednostki, [w:] M. Tyszkowa, B. Żurawkowski (red.), Wartości w świecie dziecka i sztuki dla dziecka, PWN, Warszawa 1984, s. 28.

\footnotetext{
${ }^{34}$ H. Radlińska, Pedagogika społeczna, s. 325.

${ }^{35}$ Tamże.

${ }^{36}$ A. Kamiński, Funkcje pedagogiki społecznej, PWN, Warszawa 1974, s. 34.
} 
Wspomaganie wrastania społecznego polega na tłumaczeniu zasad współpracy, zgodnego funkcjonowania $\mathrm{w}$ grupie rówieśniczej, pomocy $\mathrm{w}$ rozwiązywaniu konfliktów i uczeniu samodzielności w tym zakresie, prowadzeniu zajęć kształtujących umiejętności społeczne poprzez modelowanie sytuacji wychowawczych czy pomocy w nawiązywaniu relacji. Są to zadania trudne, gdyż dom dziecka jest szczególnym środowiskiem wychowawczym, zdecydowanie różniącym się od środowiska domu rodzinnego. „Nauczenie wychowanków społecznych form życia [...], w tym także nawiązywania i utrzymywania stabilnych stosunków interpersonalnych, oraz zaspokajanie ich potrzeb psychicznych" ${ }^{37}$ dokonuje się w wyniku sztucznie stworzonej sytuacji wychowawczej, w środowisku instytucjonalnym. Wprowadzanie w wartości kultury polega na organizowaniu uroczystości, wspólnym świętowaniu, thumaczeniu symboli kulturowych i uczestnictwu w niej poprzez organizowanie rozmaitych wycieczek, pokazywanie dzieciom programów edukacyjnych czy kultywowanie zwyczajów i tradycji. W grupie przedszkolnej wspomaganie rozwoju w zakresie powyższych trzech sfer życia stwarza większe możliwości działania. W Domowym Przedszkolu zadania wychowawcy koncentrują się głównie wokół nauczania, natomiast na oddziale głównym obszarem działań jest opieka. Ponadto dzieci uczęszczające do przedszkola są w niemal jednakowym wieku, grupa wychowanków jest mniejsza niż na oddziale, a co najistotniejsze, możliwe jest stworzenie zarysów instytucji, rozumianej w sensie symbolicznym. Tym samym postrzegam swoją rolę wychowawcy przedszkolnego jako przewodnika, który ma szansę dostarczać ciekawych przeżyć (organizując interesujące zajęcia dla dzieci - wyprawy w nieznane, nawet jeśli jest to park kilka ulic dalej czy pasjonujący teatr cieni, jeśli używa się do niego jedynie latarki i swoich dłoni), inicjatora działań pobudzających dziecięcą wyobraźnię i twórczość (wykorzystując wszelkie dostępne materiały i pomoce dydaktyczne - od mąki po tempery, od ziemniaków po styropianowe kształty i tekturowe talerze oraz od worków na tenisówki po kolorowe tasiemki, tym samym stymulując także własną pomysłowość).

Pomoc w rozwoju odbywa się $\mathrm{w}$ relacjach między podmiotami działania w celu utworzenia instytucji symbolicznej ${ }^{38}$. Tworzenie zrębów instytucji rozumianej w sensie symbolicznym, dzięki wzajemnym relacjom, nawiązanym porozumieniom i wypracowanym kompromisom, zarówno wśród dzieci, jak i na linii dorosły-dziecko sprawia, że możliwe jest współdziałanie - najwyżej ceniona $\mathrm{w}$ pedagogice społecznej odmiana relacji. W ramach towarzyszenia w rozwoju pedagog społeczny prowadzi działania, których wynikiem jest podnoszenie umiejętności i zdolności jednostki, „to podawanie ręki osobie, która de facto pomaga

\footnotetext{
${ }^{37}$ W. Terlecka, Dom dziecka, s. 741.

${ }^{38}$ E. Marynowicz-Hetka, Pedagogika społeczna. Podręcznik akademicki, s. 510.
} 
sobie sama" ${ }^{39}$. Przesłanką metodyczną dla koncepcji towarzyszenia w rozwoju może być dążenie do poszukiwania, wydobywania i wykorzystywania sił ludzkich tkwiących w ludziach i ich środowisku życia - postulat sformułowany przez H. Radlińską ${ }^{40}$, która zdefiniowała siły społeczne jako ,zdolności jednostek i zbiorowości do przeobrażania istniejących warunków, przekształcania środowiska życia i otaczającej ich rzeczywistości społecznej”’1.

Owo przekształcanie środowiska życia $\mathrm{w}$ imię ideału można analizować za pomocą pojęcia przestrzeni i jej rozmaitych odmian. Paul-Henry Chombart de Lauwe tak je definiuje: „przestrzeń życia człowieka (w socjologicznym ujęciu opatrzona przymiotnikiem «społeczna») składa się z dwóch wymiarów: materialnego, definiowana jako miejsce przebywania ludzi (to w niej odbywaja się zjawiska społeczne, takie jak ruchliwość społeczna czy zachowania członków społeczności) oraz do jej wymiaru symbolicznego, czyli emocji i wartości" ${ }^{42}$. Bohdan Jałowiecki ${ }^{43}$ twierdząc, że ,przestrzeń, w której żyjemy, nie jest tworem natury, lecz dziełem na wskroś ludzkim, przez ludzi wytworzonym w sposób uwarunkowany czynnikami przyrodniczymi, społecznymi i kulturowymi", w swojej tezie zbliża się do poglądów głoszonych przez H. Radlińską ${ }^{44}$, która wskazywała na aspekty biologiczne, społeczne i kulturowe istotne w cyklu życia człowieka, proponując przekształcanie środowiska życia siłami ludzkimi.

Anna Przecławska, analizując pojęcie przestrzeni życia człowieka, dokonuje jeszcze bardziej szczegółowych podziałów. Twierdzi, że „los człowieka kształtuje się na przecięciu różnych wymiarów przestrzeni" ${ }^{45}$. Traktując je zarówno w wymiarze realnym, jak i wyobrażonym, wymienia przestrzenie: fizyczna, społeczna, temporalna, symboliczna, psychologiczna, informatyczna, moralną i przestrzeń transcendencji oraz podkreśla, że odmian przestrzeni może być znacznie więcej, gdyż rzeczywistość społeczna podlega procesom ciagłych przemian ${ }^{46}$. Analizując powyższe rozważania, w Domowym Przedszkolu również można wyróżnić rozmaite odmiany przestrzeni. Najbardziej oczywista, gdyż widoczną, przestrzeń stanowi naturalnie ta fizyczna, odgórnie nadana jako pomieszczenie

\footnotetext{
${ }^{39}$ E. Skoczylas-Namielska, Organizacje spoleczne - praca z rodzinq. Studium realizacji pracy socjalnej, Wydawnictwo Uniwersytetu Łódzkiego, Łódź 2008, s. 44.

${ }^{40}$ H. Radlińska, Pedagogika społeczna, s. 5.

${ }^{41}$ W. Theiss, Edukacja środowiskowa. Zarys problematyki, „Problemy Opiekuńczo-Wychowawcze" 1996, nr 10.

42 Z. Rykiel, Koncepcje przestrzeni $i$ teorie regionu a wzorce uprawiania socjologii, [w:] Z. Rykiel (red.), Nowa przestrzeń społeczna w badaniach socjologicznych, Wydawnictwo Uniwersytetu Rzeszowskiego, Rzeszów 2008, s. 18.

${ }^{43}$ B. Jałowiecki, Społeczne wytwarzanie przestrzeni, Książka i Wiedza, Warszawa 1988, s. 6.

${ }^{44}$ H. Radlińska, Pedagogika spoleczna, s. 30-31.

${ }^{45}$ A. Przecławska, Przestrzeń życia człowieka między perspektywa mikro a makro, ,Problemy Opiekuńczo-Wychowawcze" 1998, nr 9.

${ }^{46}$ Tamże.
} 
i dostępne urządzenia. Jednak, jak każdy z rodzajów przestrzeni i ta - w mojej ocenie - podlega przemianom, stanowiącym wynik działania w kierunku ulepszania środowiska życia. Podejmując pracę w Domowym Przedszkolu, dokonałam pewnych zmian aranżacji przestrzennej, które moim zdaniem wpłynęły na poczucie bezpieczeństwa i komfortu biopsychicznego dzieci, a także na relacje między nimi. Wymieniłam stół i krzesła nierównej wysokości, które wcześniej stanowiły źródło bezsensownych konfliktów między wychowankami (wszyscy chcieli siedzieć „przy dużym stole” i na „dużym krześle”). Obecnie każdy z wychowanków zajmuje swoje miejsce według aktualnych sympatii i antypatii, bez koncentrowania się na elementach przestrzeni fizycznej, które mogłyby sugerować nierówność statusów. Każde dziecko rozpoczynające naukę i zabawę w Domowym Przedszkolu otrzymuje swoją indywidualną szufladę na prace plastyczne i Karty Pracy. Szuflad jest dwukrotnie więcej niż dzieci, więc ich wybór nie stanowi źródła konfliktów.

Wybór szuflady i późniejsze pasowanie na Domowego Przedszkolaka to elementy przestrzeni symbolicznej, w skład której wchodzą liczne rytuały, także dnia codziennego w Przedszkolu Domu Dziecka dla Małych Dzieci. Jednym z najważniejszych rytuałów jest śpiewanie codziennie rano piosenki powitalnej. Dzieci przedszkolne, wchodząc do Sali, stwierdzają często - ,przywitajmy się”. Ja również wielokrotnie używałam tego zwrotu, mając na myśli sugestię do zaśpiewania krótkiego utworu powitalnego. Podobnym stwierdzeniem, które ma wymiar hasła rozumianego tylko wewnattrz grupy przedszkolnej, jest „gramy w kotka?” (dotyczy loteryjki obrazkowej, której pełna nazwa to „Kot w worku”). Schematy w porozumiewaniu się z jednej strony budują poczucie wspólnotowości i przynależności do grupy, a z drugiej - kształtują przestrzeń wzajemnych relacji. Jest to element przestrzeni społecznej placówki, czyli najbardziej rozbudowanej i pełnej znaczeń, gdyż składają się na nią niewidzialne siły ludzkie ${ }^{47}$ - wyobrażenia, relacje interpersonalne, potrzeby czy odczucia zarówno uczestników, jak i pracowników instytucji.

Lucyna Telka ${ }^{48}$ ujmuje przestrzeń społecznąjako tę złożoną z relacji i wyobrażeń społecznych. W przestrzeni społecznej zachodzą istotne dla procesu wychowania zdarzenia, takie jak komunikacja i współdziałanie, pomoc czy opieka ${ }^{49}$. Odbywają się one w toku relacji interpersonalnych, które można tłumaczyć jako „długotrwałe oddziaływanie jednostek na siebie" ${ }^{50}$. O ile przekształcanie przestrzeni fizycznej jest dość prostym zadaniem, to budowanie i wprowadzanie zmian w przestrzeni społecznej stanowi długotrwały proces, oparty na licznych

${ }^{47}$ E. Marynowicz-Hetka, Pedagogika społeczna. Podręcznik akademicki, s. 512.

${ }^{48}$ L. Telka, Przekształcanie przestrzeni społecznej placówki: studium społeczno-pedagogiczne na przykładzie żłobków, Wydawnictwo Uniwersytetu Łódzkiego, Łódź 2007, s. 22.

${ }^{49}$ Tamże, s. 49.

${ }^{50}$ M. Argyle, Psychologia stosunków międzyludzkich, PWN, Warszawa 1991, s. 178. 
negocjacjach, przekraczaniu granic i kształtowaniu poczucia wspólnotowości. Co istotne, układ przestrzeni społecznej nie jest dany raz na zawsze. Odnosze niekiedy wrażenie, że codziennie konieczne są nowe porozumienia, thumaczenie reguł i ustalanie ich na nowo.

\section{Dylematy, trudności i szanse związane z kompensacją sieroctwa w opisywanej placówce}

Wychowankowie Domu Dziecka dla Małych Dzieci są głównie w wieku poniemowlęcym, przedszkolnym i wczesnoszkolnym. Potrzebują niemal stałego kontaktu (zarówno wzrokowego, jak i dotykowego) z osobą dorosłą. W domu dziecka realizacja tej potrzeby jest $\mathrm{w}$ dużej mierze utrudniona, jeśli nie niemożliwa. Dzieci poszukują uwagi opiekuna i starają się ją zdobyć rozmaitymi sposobami (od przytulania się, płaczu, po krzyk, niszczenie przedmiotów, agresję i autoagresję). Niestety, dyżur na oddziale w ciagu dnia sprawują dwie lub trzy osoby, natomiast w nocy opiekę nad grupą kilkanaściorga dzieci pełni jedna wychowawczyni lub opiekunka. Dążenie do sprawiedliwego traktowania wszystkich dzieci i obdzielania ich swoim czasem czy afektami po równo stanowi trudne wyzwanie. „Brak stałego opiekuna dziecka, poczynając od kilku miesięcy jego życia do końca wieku przedszkolnego, zbyt częste zmienianie go, [a także] niezaspokojenie potrzeb [...] bezpieczeństwa i miłości deformuje rozwój" ${ }^{51}$. Zobrazowany cytatem $\mathrm{W}$. Terleckiej problem jest mniej uciążliwy i łatwiejszy do zniwelowania w Przedszkolu, gdyż tu zajęcia prowadzone są przez cały rok szkolny tylko przez jedną osobę, a kontakty dziecka z dorosłym są systematyczne (codziennie od poniedziałku do piątku, w stałych godzinach) i w mniejszej grupie, co daje szansę na zindywidualizowanie i nawiązanie relacji.

Uczucia odgrywają znaczącą rolę w kompensowaniu sieroctwa i pracy opiekuńczo-wychowawczej z małym dzieckiem. Obok uczuć dziecka, według mnie warto także podjąć refleksję nad tym, co dzieje się w sercu i umyśle dorosłego - wychowawcy, który w codziennej pracy styka się z dramatem rodzin w kryzysie, smutkiem dzieci pozbawionych troski i opieki rodziców, ubóstwem, niekiedy także chorobami i zaburzeniami psychofizycznymi. Tego typu doświadczenia stanowią obszar działań przedstawicieli profesji społecznych. Mogą one prowadzić do dylematów związanych z przenikaniem się w pracy socjalno-wychowawczej dwóch obszarów życia - prywatnego i publicznego. Hannah Arendt ${ }^{52}$ wskazuje, że już w czasach starożytnych spostrzeżono, iż człowiek podejmuje działanie w opozycyjnych sferach - prywatnej i publicznej. Świat publicznego działania obejmuje takie idee, jak równość społeczna, wolność, sprawiedliwość. Do działalności

\footnotetext{
${ }^{51}$ W. Terlecka, Dom dziecka, s. 741.

${ }^{52}$ H. Arendt, Kondycja ludzka, Fundacja Aletheia, Warszawa 2000, s. 27.
} 
w sferze publicznej należą potrzeby uznania i bycia pozytywnie ocenianym przez innych członków grupy, dążenie do osiagnięcia wysokiego statusu społecznego poprzez właściwe wypełnianie ról społecznych, w tym również podejmowanie pracy zarobkowej oraz pomnażanie publicznego dobra. Obszar prywatnego działania koncentruje się wokół wartości, jakimi są rodzina, wspólnota, prywatność, własność. Stanowi przestrzeń dla przeżywanych uczuć i namiętności, ale także refleksji nad sobą i podejmowanym działaniem ${ }^{53}$. Hannah Arendt podkreśla, że funkcjonowanie na obu płaszczyznach jest dla człowieka niezbędne, ponieważ sfera prywatna pełni funkcję bufora emocji, a także skrywa to, czego człowiek nie powinien ujawnić domenie publicznej ${ }^{54}$. Obcowanie w pracy zawodowej z problemami rodzin i wielorakimi trudnościami dzieci, obserwowanie skomplikowanych sytuacji życiowych, negatywnych przeżyć, łez i cierpienia z pewnością nie jest łatwym zadaniem i może prowadzić do wypalenia zawodowego. Pracownik Domu Dziecka ma obowiązek ,tworzenia serdecznej atmosfery, sprzyjającej poczuciu bezpieczeństwa i wszechstronnemu rozwojowi dzieci" ${ }^{55}$, zatem powinien przejawiać empatię, współczucie, opanowanie ${ }^{56}$, opiekuńczość (afekty typowe dla sfery prywatnej) w ramach obowiązków zawodowych (związanych z obszarem działań publicznych).

Jak zauważa Jean-Marie Barbier ${ }^{57}$, w profesjonalnym działaniu człowieka można wyodrębnić ramy określające owo działanie. Dotyczą sfery intelektualnej (ramy teoretyczno-metodologiczne), emocjonalnej (ramy afektywne) i sprawczej (ramy aksjologiczne). Zgodnie z powyższą koncepcją, pojęcie ram działania nierozerwalnie wiąże się z wyobrażeniami podmiotu o działaniu, czyli postrzeganiem swoich umiejętności i wiedzy, uznawanej perspektywy teoretycznej i światopoglądowej. Wychowawca w Domu Dziecka dla Małych Dzieci musi się legitymować wykształceniem wyższym, a zatem (przynajmniej w założeniu), powinien posiadać bagaż wiedzy niezbędnej do podjęcia profesjonalnych działań kompensacyjnych, opiekuńczych i wychowawczych.

Wśród odniesień teoretyczno-metodologicznych znajdują się konstrukty świadomościowe, przyjęte koncepcje i wyznawane idee ${ }^{58}$. Podejmowane działanie zależy zatem od posiadanej wiedzy i kompetencji (metodycznych, metodologicznych), jednak brak pewnych umiejętności również może kształtować

${ }^{53}$ Tamże, s. 33-86.

54 Tamże, s. 79.

${ }^{55}$ Zakres obowiązków odpowiedzialności i uprawnień na stanowisku wychowawcy Domu Dziecka dla Małych Dzieci w Łodzi, cz. I, pkt 1, s. 1.

${ }^{56}$ C. Sutton, Psychologia dla pracowników socjalnych, Gdańskie Wydawnictwo Psychologiczne, Gdańsk 2004, s. 73.

${ }^{57}$ J.-M. Barbier, Działanie w kształceniu i pracy socjalnej, [w:] E. Marynowicz-Hetka, Pedagogika społeczna. Podręcznik akademicki, s. 239.

${ }^{58}$ Tamże, s. 240. 
działanie, zależne wówczas od intuicji podmiotu działającego. Lucyna Telka ${ }^{59}$ wskazuje, że ramy działania mogą ulegać przekształceniom, tak więc można sądzić, iż każdy podmiot działający w polu praktyki pracy społecznej/socjalnej, zdobywając nowe doświadczenia i dokształcając się, uczy się i na nowo tworzy swoje ramy działania.

Do ram afektywnych należą: „emocje, afekty, elementy wolicjonalne podmiotu działającego" ${ }^{60}$. To przeżycia towarzyszące w danej chwili wychowawcy, jak i subiektywne przekonanie o możliwości działania (mocy sprawczej). Urszula Kamińska podkreśla, że ,wiara lub niewiara we własne możliwości skutecznego działania wpływa istotnie na to, jak ludzie działają w rzeczywistości”" ${ }^{6}$. Jak już zauważyłam, emocje odgrywają ogromną rolę w pracy z małym dzieckiem pozbawionym opieki ze strony rodziny naturalnej. Są nieodzownym elementem codziennych działań - w dużej mierze to przez afekty i doświadczenia przenikają się sfery publiczna i prywatna. Niezwykle istotnym elementem afektywnych ram działania wychowawcy w Domu Dziecka dla Małych Dzieci jest nauczenie się zarówno rozpoznawania, nazywania oraz dawania upustu własnym emocjom, jak i odpowiedniego reagowania na przeżycia i uczucia wyrażane przez dzieci.

Trzeci rodzaj ram działania to ramy aksjologiczne, czyli wartości ${ }^{62}$, o których powinien pamiętać wychowawca. Jak stwierdza L. Telka ${ }^{63}$, wartości mają fundamentalne znaczenie dla działania w obszarze profesji społecznych, gdyż dają możliwość określenia, z kim, dla kogo i w jakim celu podejmuje się działanie. Poprzez aksjologiczne ramy działania można zorientować podejmowane wysiłki na podmiot, a nie przedmiot działań ${ }^{64}$.

Decyzje podejmowane przez wychowawcę w toku praktycznego działania $\mathrm{w}$ istotnym stopniu zależą od posiadanej wiedzy, pozyskanej w procesie kształcenia, osobowości, cech charakteru czy przekonań aksjologicznych. Ramy działania w dużej mierze są weryfikowane w polu praktyki, a zderzenie z rzeczywistością społeczną może być bolesne. W moim przypadku - absolwentki studiów z pedagogiki społecznej, kształconej w toku licencjackim i magisterskim - takim zderzeniem była realizacja projektu socjalnego ${ }^{65}$. Przebiegała niczym zapis fali sinusoidalnej - od huraoptymistycznych poczynań koncepcyjnych (mnóstwo ciekawych pomysłów) do możliwości ich realizacji (niewielkie zasoby, nieznaczne wsparcie w placówce, której wychowankowie byli adresatami projektu, niechęć

\footnotetext{
${ }^{59}$ L. Telka, Przeksztatcanie przestrzeni spolecznej placówki..., s. 144-145.

${ }^{60}$ J.-M. Barbier, Działanie w ksztatceniu i pracy socjalnej, s. 240.

${ }^{61}$ U. Kamińska, Zranione dzieciństwo. Wychowankowie Domu Dziecka mówiq, Wydawnictwo „Śląsk”, Katowice 2000, s. 37.

${ }^{62}$ E. Marynowicz-Hetka, Pedagogika społeczna. Podręcznik akademicki, s. 241.

${ }^{63}$ L. Telka, Przeksztatcanie przestrzeni społecznej placówki..., s. 146.

${ }^{64}$ Tamże.

${ }^{65}$ Projekt Okno na świat zrealizowany w 2010 r. w jednym z łódzkich domów dziecka.
} 
samych adresatów i spory pomiędzy realizatorkami projektu sprawiły, że projekt ewoluował), od euforii, gdy osiagano zamierzone cele, po spadek nastroju wskutek niepowodzeń. Wielogodzinny pobyt w domu dziecka sprawił, że dobitnie zrozumiałam stwierdzenie H. Radlińskiej, aby ,tak nastawić wyobraźnię społeczna, by przestała się lubować w jaskrawych efektach i wyzwoliła się z magii wielkich liczb"66. Brak widocznych, szybkich efektów działań, niezrealizowanie celów i zadań, mimo intensywnego wysiłku i zaangażowania niweczy nawet największy optymizm i zapał. To istotne, że takie zderzenie z rzeczywistością społeczną ma miejsce już na I stopniu studiów - dzięki czemu można tak nastawić swoją wyobraźnię, aby cieszyła się najmniejszymi sukcesami i nie zniechęcała się w wyniku doznanych porażek. W toku refleksji nad działaniem podejmowanym w ramach projektu ukształtowały się teoretyczne ramy działania - wybrałam obszar zainteresowań społeczno-pedagogicznych oraz zinterioryzowałam teorie i koncepcje, które towarzyszą mi w aktywności zawodowej i myśleniu nad działaniem do chwili obecnej. Te doświadczenia w dużej mierze pomogły mi stawić czoła wyzwaniom związanym z pisaniem pracy magisterskiej, szukaniem pracy oraz realizacją obowiązków zawodowych. W pracy opiekuńczo-wychowawczej podejmowanej na oddziale mogłam ze spokojem stwierdzać, że skutki działania zależą nie tylko od zaangażowania i wiedzy wychowawcy, lecz przede wszystkim od podmiotu, z/dla/wobec którego się działa, kontekstu społecznego oraz rozmaitych uwarunkowań, niezależnych od działającego. Jednak po trzech latach pracy na oddziale otrzymałam propozycję prowadzenia Domowego Przedszkola, które zmieniło moje myślenie o działaniu i sprawiło, że dokonałam reorientacji poglądów. Nadal wiem, że spektakularne sukcesy jako skutki podejmowanych działań nie są udziałem pedagoga społecznego (przynajmniej nie na co dzień), lecz dostrzegam sens swojej pracy. O ile pracując z dziećmi w wieku poniemowlęcym, przedszkolnym i wczesnoszkolnym na oddziale postrzegałam wymiar własnych działań jako zaspokajanie dziecięcych potrzeb niższego rzędu i całodobową opiekę, to obecnie, prowadząc Domowe Przedszkole, dążę do osiagania celów, które kojarzę z potrzebami akceptacji, przynależności, wszechstronnego rozwoju i twórczości dzieci. Jednocześnie mogę stwierdzić, że dążąc do kompensacji niepomyślnej sytuacji życiowej i wspierania rozwoju moich przedszkolaków, sama mogę się rozwijać, widząc wartość swojej pracy.

Proces kształcenia pedagoga społecznego w moim przypadku przebiegał w toku tworzenia szeroko rozumianego obszaru zainteresowań, który wyodrębnił się jako kompensacja sieroctwa już na etapie studiów licencjackich i ewoluował w trakcie realizacji projektu socjalnego. Już wtedy zainteresowałam się tematyką ram działania społecznego, dylematów napotykanych w pracy socjalno-wychowawczej oraz przestrzeni społecznej, którą analizowałam także podczas

${ }^{66}$ H. Radlińska, Pedagogika społeczna, s. 328. 
opracowania pracy magisterskiej. Powyższa rama teoretyczna oraz obszar praktycznego działania towarzyszą mi także teraz, w podejmowanej praktyce opiekuńczej, wychowawczej i dydaktycznej. Ten tekst, stanowiący próbę refleksji nad działaniem, również powstał w oparciu o preferowane przeze mnie koncepcje naukowe i wnioski wybranych autorów.

\section{Bibliografia}

\section{Pozycje zwarte}

Andrzejewski M., Domy na piasku. Rzecz o sieroctwie i domach dziecka, Wydawnictwo „W drodze”, Poznań 1997.

Argyle M., Psychologia stosunków międzyludzkich, PWN, Warszawa 1991.

Arendt H., Kondycja ludzka, Fundacja Aletheia, Warszawa 2000.

Jałowiecki B., Społeczne wytwarzanie przestrzeni, Książka i Wiedza, Warszawa 1988.

Kamińska U., Zranione dzieciństwo. Wychowankowie Domu Dziecka mówiq, Wydawnictwo „Śląsk”, Katowice 2000.

Kamiński A., Funkcje pedagogiki społecznej, PWN, Warszawa 1974.

Marynowicz-Hetka E., Pedagogika społeczna. Podręcznik akademicki, t. 1, PWN, Warszawa 2007.

Radlińska H., Pedagogika społeczna, Ossolineum, Warszawa 1961.

Skoczylas-Namielska E., Organizacje społeczne - praca z rodzinq. Studium realizacji pracy socjalnej, Wydawnictwo Uniwersytetu Łódzkiego, Łódź 2008.

Sutton C., Psychologia dla pracowników socjalnych, Gdańskie Wydawnictwo Psychologiczne, Gdańsk 2004.

Telka L., Przeksztatcanie przestrzeni społecznej placówki: studium społeczno-pedagogiczne na przykładzie żłobków, Wydawnictwo Uniwersytetu Łódzkiego, Łódź 2007.

\section{Artykuły}

Barbier J.-M., Dziatanie w kształceniu i pracy socjalnej, [w:] E. Marynowicz-Hetka, Pedagogika społeczna. Podręcznik akademicki, t. 1, PWN, Warszawa 2007.

Bragiel J., Rodzina obszarem pracy socjalnej, [w:] J. Bragiel, P. Sikora (red.), Praca socjalna - wielość perspektyw. Rodzina - multikulturowość - edukacja, Wydawnictwo Uniwersytetu Opolskiego, Opole 2004.

Dunaj J., Komunikacja stowna w placówce opiekuńczo-wychowawczej, „Problemy Opiekuńczo-Wychowawcze" 2009, nr 7.

Kaczmarek M., Dekada przekształceń domów dziecka, „Problemy Opiekuńczo-Wychowawcze” 2010, $\mathrm{nr} 1$.

Przecławska A., Przestrzeń życia człowieka między perspektywa mikro a makro, „Problemy Opiekuńczo-Wychowawcze" 1998, nr 9.

Rykiel Z., Koncepcje przestrzeni i teorie regionu a wzorce uprawiania socjologii, [w:] Z. Rykiel (red.), Nowa przestrzeń społeczna w badaniach socjologicznych, Wydawnictwo Uniwersytetu Rzeszowskiego, Rzeszów 2008.

Siwek S., Sieroctwo społeczne $w$ genezie nieprawidłowego rozwoju, „Problemy Opiekuńczo-Wychowawcze" 2009, nr 6.

Terlecka W., Dom dziecka [w:] K. Ablewicz, T. Pilch (red.), Encyklopedia pedagogiczna XXI wieku, Wydawnictwo Akademickie „Żak”, Warszawa 2008.

Theiss W., Edukacja środowiskowa. Zarys problematyki, „Problemy Opiekuńczo-Wychowawcze” 1996, nr 10. 
Tyszkowa M., Kultura symboliczna. Wartości i rozwój jednostki, [w:] M. Tyszkowa, B. Żurawkowski (red.), Wartości w świecie dziecka i sztuki dla dziecka, PWN, Warszawa 1984.

\section{Przepisy prawne}

Rozporządzenie Ministra Pracy i Polityki Społecznej z dnia 19 października 2007 r. w sprawie placówek opiekuńczo-wychowawczych.

Ustawa o wspieraniu rodziny i pieczy zastępczej z dnia 9 czerwca 2011 r., http://isap.sejm.gov.pl/ DetailsServlet?id=WDU20111490887 (dostęp: 2.03.2016).

\section{Inne}

Główny Urząd Statystyczny, Opieka nad dzieckiem pozbawionym opieki, Warszawa 2014.

Łongwa-Kurosz M., Rejestr wolnych miejsc w placówkach opiekuńczo-wychowawczych, regionalnych placówkach opiekuńczo-terapeutycznych i interwencyjnych ośrodkach preadopcyjnych funkcjonujacych na terenie województwa tódzkiego, stan z dnia 31.01.2016 r.

Podstawa Programowa Ministerstwa Edukacji Narodowej dla przedszkoli, oddziałów przedszkolnych w szkołach podstawowych i innych form wychowania przedszkolnego.

Zakres obowiązków odpowiedzialności i uprawnień na stanowisku wychowawcy Domu Dziecka dla Małych Dzieci w Łodzi.

www.domdlamalucha.info (dostęp: 14.03.2016). 